beyond the limits of the meeting and of the association. The Mathematical Association met in the same building, and it was unfortunate that arrangements were not made so that the two presidential addresses at least could be attended by members or poth associations. Good service has been done by the Teachers' Guild, on the initiative of which thirteen associations met by agreement in the University of London and had a kind of British Association week of meetings. At one of the guild meetings Miss Sheavyn directed attention to the mode of entry into the higher grades of the Civil Service. Of the first hundred in the last competition fifty-nine scored chiefly in classics, twentynine in mathematics, and twelve in other subjects. (One gathers that science is not wanted or that proficiency in science is not esteemed as evidence of mental culture.) Miss Sheavyn regretted that in technical posts requiring qualifications in science, e.g. posts at the British Museum, the question of opening them to suitable women should not be considered, notwithstanding the difficulty experienced at times in getting applicants.

Miss I. M. Drummond, in her presidential address to the Assistant-mistresses in Public Secondary Schools, discussed "the scientific study of living things as an element in education." She said that they were urged by social reformers to teach girls certain definite biological facts, notably those of human physiology and reproduction; but there was too little appeal for real training in biological thought. In this age people did not set as high a value as they should on the energising power of ideas. Some knowledge of a living body was valuable, but she did not think it followed that a course of human physiology should always be introduced. If the school course included animal anatomy, more definite physiological teaching would find a natural place, and on such a foundation she would base teaching in hygiene. Training in scientific biology was a real and helpful preparation for entering sympathetically into the thought-life of the time.

A somewhat different line of argument was taken by Prof. Starling at the L.C.C. Conference. We hope to refer to this in a future article, to which also we postpone consideration of the discussion at the Association of Teachers in Domestic Subjects.

G. F. Danifll.

PRIZES PROPOSED BY THE PARIS
ACADEMY OF SCIENCES FOR I9I4.

GEOMETRY.-The Francour prize (I000 francs), $G$ for discoveries or works useful to the progress of pure and applied mathematics; grand prize of the mathematical sciences ( 3000 francs), for an improvement in the theory of functions of one variable which are susceptible of representations by trigonometrical series of several arguments, linear functions of this variable; Poncelet prize (2000 francs), for work in pure mathematics.

Mechanics.-Montyon prize (700 francs), for the invention or improvement of instruments useful to the progress of agriculture, the mechanical arts, or sciences; Henri de Garville prize (I500 francs), for original work in mechanics; Fourneyron prize (I00o francs), for a theoretical and experimental study of the question of combustion of explosion turbines.

Navigation.-.-The extraordinary prize of 6000 francs, as a recompense for work increasing the efficiency of the French naval forces; Plumey prize (4000 francs), for improvements or inventions rontributing to the progress of steam navigation.

Astronomy.-The Lalande prize (540 francs), for the most interesting observation, memoir or work useful No. 2256 , voL. 90] to the progress of astronomy; the Valz prize $(460$ francs), for the most interesting astronomical observation during the year; the Janssen prize (a gold medal), for a discovery or work representing an important advance in physical astronomy; the Damoiseau prize (2000 francs), for an improvement in Le Verrier's tables of Jupiter.

Geography. - The Tchihatchef prize (3000 francs), for the encouragement of naturalists of any nationality who have made explorations in the lesser-known parts of Asia; the Gay prize (I500 francs), for a study of the distribution of hydraulic forces in a mountainous region, with a description of the methods and instruments employed in this research; the Binoux prize (2000 francs), for work on geography; the Delalande Guérineau prize (1000 francs).

Physics.-The Hébert prize (1000 francs), for a treatise or discovery extending the practical use of elyztricity; the Hughes prize (2500 francs), for work contributing to the progress of physics; the Victor Raulin prize ( $5_{5} 00$ francs), for facilitating the publication of works relating to meteorology and physics of the globe; the La Caze prize (10,000 francs), to the author of works or memoirs contributing to the progress of physics.

Chemistry.--The Jecker prize (10,000 francs), for work in organic chemistry; the Cahours prize (3000 francs), for the encouragement of young workers in chemistry; the Montyon prize (unhealthy trades, a prize of 2500 francs and a mention of 1500 francs), for work rendering an art or trade less unhealthy; the L. La Caze prize (10,000 francs), for work in the field of chemistry.

Mineralogy and Geology.-The Fontannes prize (2000 francs), for a palæontological publication.

Botany.-The Desmazières prize (1600 francs), for a work on Cryptogams; the Montagne prize (1500 francs), for researches on the anatomy, physiology, development, and description of the lower Cryptogams; the De Coincy prize ( 900 francs), for a work on Phanerogams.

Anatomy and Zoology.-The Savigny prize (1500 francs), for the assistance of young travelling znologists, not receiving Government aid, who occupy themselves with the invertebrates of Egypt and Syria; the Thore prize (200 francs), for the best work on the habits and anatomy of a species of European insect; the Cuvier prize ( ${ }_{500}$ francs), for a work on zoological palæontology, comparative anatomy, or zoology.

Medicine and Surgery.-The Montyon prize (2500 francs, mentions of I5oo francs); the Barbier prize (2000 francs), for a valuable discovery in surgical, medical, or pharmaceutical science, or in botany having relation to medicine; the Bréant prize (100,000 francs), for a means of curing Asiatic cholera; the Godard prize (I000 francs), for a memoir on the anatomy, physiology, and pathology of the genitourinary organs: the Baron Larrey prize (750 francs), to a naval or army surgeon or doctor, for a work dealine with military medicine, surgery, or hygiene; the Bellion prize (r400 francs); the Mège prize (ro,ono francs).

Physiology.-The Montyon prize (750 francs), for work in experimental physiology: the Philipeaux prize foo francs), for the same; the Lallemand prize (I80o francs), for work relative to the nervous system; the Pourat prize (rooo francs), for a memoir on the origin of the anti-ferments; the I. I a Caze prize (10,000 francs), for a work on physiology; the MartinDamourette prize ( 400 francs), for a work on therapeutic physiology.

Statistics.--The Montvon prize (Ioon francs, two reentions of 500 francs). 
History of Science.-The Binoux prize (2000 francs). General Prizes.-The Arago, Lavoisier, and Berthelot medals; the Henri Becquerel prize (3000 francs); the Gegner prize ( 3800 francs); the Lannelongue prize (2000 francs), for men of science or their relatives in need of assistance; the Gustave Roux prize (1000 francs); the Trémont prize (I 100 francs); the Wilde prize (4000 francs, or two of 2000 francs), for discoveries in astronomy, physics, chemistry, mineralogy, geology, or experimental mechanics; the Lonchampt prize (4000 francs); the Saintour prize (3000 francs), for researches in the physical sciences; Henri de Parville (2500 francs); the Victor Raulin prize (I500 francs), for facilitating the publication of works relating to meteorology; the Houllevigue prize (500o francs); the Caméré prize (4000 francs); the Jerome Ponti prize (3500 francs); the Bordin prize (3000 francs), for a study of the nature and origin of the gases and emanations from the terrestrial globe; the Serres prize (7500 francs), for works on general embryology applied to physiology and medicine; the Jean Jacques Berger prize ( 15,000 francs); the prize founded by Mme. la Marquise de Laplace; the Félix Rivot prize (2500 francs).

\section{BRITISH MEDICAL SCIENCE AT THE GHENT INTERNATIONAL EXHIBITION.}

$\mathrm{NE}$ of the most important sections of the British exhibit at the forthcoming International Exhibition at Ghent will be an organised demonstration of the progress that has been made in this country in the scientific investigation of tropical diseases and of their prevention and cure. The exhibit has been carefully planned by a committee composed of members of the various schools of tropical medicine, and each school deals specially with certain diseases. The London School, represented on the committee by $\mathrm{Dr}$. H. B. Newham, is dealing with beri-beri, cholera, filariasis, and guinea-worm. The exhibit of the Liverpool School, prepared by Dr. J. W. W. Stephens and Prof. Newstead, will be devoted to the subjects of malaria, sleeping sickness, yellow fever, and ankylostomiasis.

The Royal Army Medical College, under the direction of Lieut.-Col. Sir William Leishman, is undertaking exhibits of enteric fever and leishmaniasis, tise former arranged in five sections to illustrate respectively the causation, diagnosis, dissemination, pathology, and vaccine treatment, the latter in three sections dealing with Indian kala-azar, infantile kalaazar, and Oriental sore. Malta fever is allotted to the Admiralty under the direction of Fleet-Surgeon P. W. Bassett-Smith, and plague to the India Office, represented by $\mathrm{Sir}$ A. M. Branfoot. Dr. Andrew Balfour, of Khartum, is preparing the exhibit relating to leprosy. In addition to the work of the schools, an exhibit will be sent by the Natural History Museum to illustrate the problems of natural history, such as life-cycles of the parasites, structure and life-histories of their insect-carriers, \&c., specially connected with the study of tropical diseases.

In each case the disease will be considered, so far as possible, from the various points of view of distribution, cause, pathological effects, dissemination, treatment, and prophylaxis. The exhibits will comprise specimens, models, coloured drawings, or photographs of the parasites that cause the disease, and of the insects that transmit them, illustrating their structure and life-histories; charts, maps, and statistics showing the distribution and incidence of the disease, results of treatment, \&c.; and specimens or models of apparatus used in treatment or prevention, such as, for example, models of mosquito-proof port- holes and cabins on ships. In the case of beri-beri specimens of rice will be shown illustrating the causation of the disease, and in the case of sleeping sickness heads and skins will be exhibited of the species of antelope and other wild game which harbour the trypanosome.

The entire exhibit, the details of which are now practically complete, will be, it is hoped, a striking testimony to the wide range and great importance of the investigations upon tropical diseases that are being carried on in this country.

\section{UNIVERSITY AND EDUCATIONAL INTELLIGENCE.}

CAMBridge.-The prize of $50 l$. from the Gordon Wigan fund for a research in chemistry was awarded in the year 1912 to Mr. D. H. Peacock, for investigations on hydroxyhydrindenehydrazine and its resolution, I:2:4-triketopentamethylene, the theory of molecular volumes.

The Senate authorised some time ago the erection of the eastern half of the forestry building, as soon as adequate funds have been provided. More than $4500 l$. has now been privately subscribed, and a grant from the Development Fund will enable the erection of the building to be taken in hand immediately. The cost of the contemplated building will exceed 50ool., and the grant will therefore amount to $2500 l$. The forestry committee recommends that the grant by the Treasury of a sum of $2500 l$., which is required to defray half the cost of the eastern portion of the forestry building, be accepted, and that the ViceChancellor be authorised to convey to the Development Commissioners the thanks of the University for the grant now authorised, and for their promise of a future grant when an extension of the forestry building will be required.

It is proposed to confer the degree of master of arts, honoris causa, upon Mr. G. Udny Yule, University lecturer in statistics.

OXForD.-The Herbert Spencer lecture this year will be delivered by Dr. D'Arcy Wentworth Thompson, C.B., professor of natural history, University College, Dundee, at the Examination Schools, on Thursday, February 13, at 5.30 . The subject of the lecture, which will be illustrated by lantern-slides, is " Growth and Form."

On January 28 Convocation will vote on a proposal to assign a plot of land in the University Park, to the east of the plot lately assigned for the erection of a new chemical laboratory, for the purpose of an engineering laboratory. It will be remembered that last term Convocation declined to sanction the allocation of a site for the latter purpose at the north-west corner of the park. A movement has been set on foot for acquiring land in various parts of the city for the future extension of University departments, and in particular for securing a site for the proposed engineering laboratory in the neighbourhood of Museum Road. It is understood that a sum of more than roool. has already been promised for this object, including a donation of $50 l$. from the Chancellor, Lord Curzon. On the other hand, it is urged, in a paper signed by many of the teachers of science in the University, that the Museum Road site is very unsuitable for the proposed laboratory, and it appears to be extremely doubtful whether, if the park site be refused, the other proposal will be accepted as an alternative.

According to a recent regulation issued by the Minister of Public Instruction in France all students of foreign nationality who wish to pursue their studies 